\title{
Occupation and factors associated with exposure to the sun among beach workers
}

\author{
Ocupação e fatores associados a exposição solar \\ em trabalhadores de praias
}

Eudes Euler de Souza Lucena ${ }^{1}$

Danielle Clarisse Barbosa Costa ${ }^{2}$

Éricka Janine Dantas da Silveira ${ }^{2}$

Kenio Costa Lima ${ }^{2}$

\footnotetext{
${ }^{1}$ Departamento de Odontologia, Universidade do Estado do Rio Grande do Norte, Campus Caicó. Av. André Sales 667, Paulo VI. 59.300-000 Caicó RN Brasil.

eudeseuler@hotmail.com ${ }^{2}$ Departamento de Odontologia. Universidade Federal do Rio Grande do Norte
}

\begin{abstract}
Subjects were selected from five urban beaches to characterize the type of work conducted on urban beaches in the city of Natal, state of Rio Grande do Norte, Brazil, and determine potential associated factors among workers exposed to the sun. Data collection was based on a validated questionnaire. Results were obtained for 362 workers. Individuals were predominantly male (72.6\%) who worked under direct exposure to the sun (87.8\%). Almost 95\% had no more than 6 years of schooling and $87.91 \%$ earned an average monthly income of $\$ 318.75$ dollars or more. Photoprotection was reported by $80.1 \%$, among which sunscreen and caps/hats were predominant. Around 25\% smoked and more than half did not consume alcohol. Male gender, no more than 6 years of schooling, daily exposure for up to 6 hours and use of photoprotection were the factors associated with the outdoor work category. Key words Epidemiology, Occupational medicine, Exposure to the sun, Community work
\end{abstract}

Resumo Para caracterizar o tipo de trabalho realizado nas praias urbanas na cidade de Natal, $R N$, Brasil, e determinar possiveis fatores associados entre trabalhadores expostos ao sol, foram selecionados sujeitos em cinco praias urbanas. A coleta de dados foi baseada em um questionário validado. Os resultados foram obtidos para 362 trabalhadores. Indivíduos eram predominantemente do sexo masculino (72,6\%), que trabalharam sob exposição direta ao sol (87,8\%). Aproximadamente 95\% tinham até 6 anos de escolaridade e $87,91 \%$ ganhavam em média \$318,75 dólares ou mais por mês. Medidas de fotoproteção foram relatadas por $80,1 \%$, entre os quais protetor solar e bonés/chapéus se destacaram. Cerca de 25\% fumava e mais da metade não bebia álcool. O gênero masculino, escolaridade até 6 anos, a exposição diária por até 6 horas e o uso de fatores de fotoproteção foram associados com a categoria de trabalhado outdoor.

Palavras-chave Epidemiologia, Medicina ocupacional, Exposição solar, Trabalho comunitário 


\section{Introduction}

Worker's health is understood as the set of actions responsible for the promotion, protection, recovery and rehabilitation of their physical and mental well-being. The relationship between work and health has been increasingly discussed over the last two decades. Theory focuses on the work/ health process, considering work loads as a complex whole where interaction between parties is procedural $^{1}$. The increase in the number of workers linked to diverse forms of employment contract, such as outsourcers or task order contracts, has resulted in precarious employee protection conditions ${ }^{2}$.

The term "exposure" means contact with any attribute that may be relevant to individual health. These can include environmental, biological or socioeconomic factors, which act in isolation or in conjunction with genetic factors. In these situations, individuals are exposed to a specific substance, a mixture of substances or a work process ${ }^{1}$.

Certain professions are associated with the onset of work-related illnesses. Employees exposed to physical, chemical or biological agents are more prone to be carriers of such diseases. A classic example is those with documented or undocumented status working on beaches, since they are directly or indirectly exposed to ultraviolet radiation from sun exposure.

The low socioeconomic status of these individuals, as well as the small number of jobs available to those with little qualification, influences the increase in the number of undocumented workers. These individuals often expose themselves to a variety of workplace hazards in order to ensure their livelihood. The difference in perceived risk between the sexes does not occur among varying social strata. Excessive exposure is equally reported by individuals with greater and lower purchasing power, varying only in the circumstances of exposure. Those with higher socioeconomic and schooling levels are more prone to experience sunburn during leisure activities, while those with lower socioeconomic and schooling levels are more likely to do so when working ${ }^{3,4}$.

Thus, the present study aimed to characterize the type of worker involved in occupational activities on the main urban beaches in the city of Natal/RN - Brazil with regard to sun exposure, and determine potential associations with sociodemographic, occupational and general health variables.

\section{Methodology}

The present study is a population survey providing an important view towards understanding occupations carried out by beach workers and in determining the association of certain factors with the work involved. From an operational perspective, this is a study with individual-level data. With regard to the position of the researcher, it is observational, and, in relation to the timeframe, is classified as cross-sectional ${ }^{5}$.

The project was approved by the Research Ethics Committee (CEP) at the Federal University of Rio Grande do Norte in accordance with Resolution 196/96 of the National Health Council.

Workers on Ponta Negra, Redinha, Meio, Forte and Artistas Beaches in the city of Natal, Brazil participated in this study. Participants were adult and elderly males and females and used those places to get the principal source of income. The sample was calculated based on the sampling design from "Prevalence and factors associated with lip and perioral lesions resulting from sun exposure in beach workers" was first conducted with $10 \%$ of the sample universe, owing to the absence of estimates regarding the number of workers, which compromised calculation of actual sample size. Two evaluators went to the collection sites over 2 weekends and observed 1200 workers, resulting in a sample of 120 individuals. Based on the prevalence of lip lesions obtained in the pilot study $36.6 \%$ (the lowest prevalence), and considering a margin of error of $15 \%$ and non-response rate of $20 \%$, a final sample of 355 individuals was obtained. The methods to the pilot study were the same from the main study.

Data were collected in December 2011 in areas with a significant number of beach workers. Since this period corresponds to low season, the presence of full-time workers was expected at these locations. The study was publicized beforehand in the local media through interviews with professors involved in the research. Subject allocation was non-probabilistic and individuals were invited to participate spontaneously. Data collection was based on a validated questionnaire. This instrument was validated in three steps. The first was conducted through literature search, followed by an evaluation by dentists, dermatologists and epidemiologists, and finally a cultural adaptation of the questionnaire to the universe of the study.

Calibrated students from the Dentistry and Medicine course at the Federal University of Rio 
Grande do Norte (UFRN) were responsible for gathering information. A workshop calibration was made by the teachers of the Department of Dentistry and Department of Dermatologist to minimize variations among different examiners. The result of the calibration process, measured by the kappa coefficient, ranged from 0.68 to 1.00 .

Outdoor workers were those exposed directly to ultraviolet radiation in around the beaches. Those working in covered places were classified as indoor. In order to understand how one or more sociodemographic, occupational or general health characteristics are distributed among beach workers in the city of Natal, as well as determine the existence of associations between type of work and sun exposure, the following variables were used:

- Dependent variable: type of work (outdoor and indoor)

- Independent variables: gender, employment status, age, years of schooling, income in dollars, time of daily sun exposure, frequency of weekly sun exposure, accumulated exposure time, work start time, work finishing time, use of photoprotection measures, skin type and habits.

Data were imported onto STATA ${ }^{\circledR}$ software platforms version 10.0 and subsequently checked for typing consistency. Association between type of work and sociodemographic, occupational and general health variables was determined using the chi-square statistical test. In order to establish the magnitude of these associations, prevalence ratios and their respective confidence intervals were applied (95\%). Multivariate analysis was performed using robust Poisson regression applying the hybrid method to estimate the extent of the relationship between independent vari- ables (sex, employment status, years of schooling, time of daily sun exposure, work start time, work finishing time, photoprotection measures, sunscreen use, use of a cap/hat and skin type) and the dependent variable. A significance level of $5 \%$ was adopted for all tests.

\section{Results}

Following data collection, results were obtained for 362 workers. Most of the sample were males $(72.6 \%)$ aged approximately 37 years old, with a mean monthly income of $\$ 318.75$ and an average of 6 years schooling. The population worked under direct sun exposure for 6 hours a day, 5 days a week over the previous 8 years (Table 1). The vast majority uses photoprotection $(80.1 \%)$, mainly a cap/hat or sunscreen. With regard to habits, a quarter of subjects smoke and more than half do not drink. In relation to skin type, based on the Fitzpatrick scale ${ }^{8}$, workers exhibited predominantly light brown and dark brown skin. Nearly all participants worked under direct sun exposure $(87.8 \%)$ for up to 6 hours daily (95.2\%); $88.5 \%$ up to five times a week and $88.3 \%$ for more than 8 years. (Table 2).

However, when relating these sociodemographic, occupational and general health variables with type of work, a greater occurrence was recorded for male outdoor workers, with 6 years of schooling who were exposed to the sun for up to 6 hours and used some means of photoprotection.

In multivariate analysis, sex, years of schooling, daily exposure and photoprotection remained significant, irrespective of other variables. Jobs in

Table 1. Sample description according to socio-demographic and occupational variables. Natal, Brazil, 2013.

\begin{tabular}{lcccccc}
\hline \multicolumn{1}{c}{ Variable } & $\mathbf{n}$ & Mean $\pm \mathbf{s d}$ & Median & Chi 25-75 & Min & Max \\
\hline Sociodemographic & & & & & & \\
$\quad$ Age & 355 & $37.17 \pm 11.88$ & 37.00 & $27.00-45.00$ & 18.00 & 68.00 \\
$\quad$ Years of schooling & 355 & $6.49 \pm 3.98$ & 6.00 & $4.00-10.00$ & 0 & 17.00 \\
$\quad$ Income in dollars & 337 & $428.76 \pm 298.70$ & 318.75 & $250.00-500.00$ & 31.25 & 2625.00 \\
Occupational & & & & & & \\
$\quad$ Start time & 361 & $8.62 \pm 1.37$ & 9.00 & $8.00-10.00$ & 5.00 & 13.00 \\
Finishing time & 361 & $15.84 \pm 1.98$ & 16.00 & $14.00-17.00$ & 8.00 & 24.00 \\
Daily exposure time in hours & 361 & $5.89 \pm 1.26$ & 6.00 & $7.00-6.00$ & 0 & 7.00 \\
Weekly sun exposure in days & 361 & $4.76 \pm 2.17$ & 5.00 & $2.50-7.00$ & 1.00 & 7.00 \\
$\quad$ Exposure in years & 361 & $10.07 \pm 9.66$ & 8.00 & $3.00-15.00$ & 0.08 & 60.00 \\
Exposure in months & 361 & $121.27 \pm 115.60$ & 96.00 & $180.00-36.00$ & 1.00 & 720.00 \\
\hline
\end{tabular}


Table 2. Frequencies, chi $^{2}$ test, p-value, PRs and respective confidence intervals for type of work associated with sociodemographic, occupational and general health variables. Natal, RN. 2013.

\begin{tabular}{|c|c|c|c|c|c|c|c|c|c|}
\hline \multirow[b]{2}{*}{ Variable } & \multirow[b]{2}{*}{$\mathbf{n}$} & \multicolumn{5}{|c|}{ Type of worker } & \multirow[b]{2}{*}{$P_{\mathrm{aj}}$} & \multirow[b]{2}{*}{ p-value } & \multirow[b]{2}{*}{ CI $(95 \%)$} \\
\hline & & $\%$ & chi $^{2}$ & p-value & $P_{\text {naj }}$ & CI $(95 \%)$ & & & \\
\hline \multicolumn{10}{|l|}{ Sex } \\
\hline Male & 239 & 90.9 & 7.260 & 0.007 & 1.139 & $1.024-1.266$ & 1.200 & 0.001 & $1.081-1.332$ \\
\hline Female & 79 & 79.8 & & & & & & & \\
\hline \multicolumn{10}{|l|}{ Employment status } \\
\hline Documented & 12 & 70.6 & 3.400 & 0.065 & 0.796 & $0.584-1.085$ & 1.128 & 0.452 & $0.824-1.545$ \\
\hline Undocumented & 305 & 88.7 & & & & & & & \\
\hline \multicolumn{10}{|l|}{ Age } \\
\hline 37 years and older & 150 & 88.2 & 0.001 & 0.976 & 1.008 & 0.933-1.089 & - & - & - \\
\hline Up to 37 years & 162 & 87.6 & & & & & & & \\
\hline \multicolumn{10}{|l|}{ Years of schooling } \\
\hline Up to 6 years & 179 & 94.2 & 14.102 & 0.001 & 1.169 & $1.076-1.270$ & 1.157 & 0.001 & $1.069-1.253$ \\
\hline 6 years and over & 133 & 80.6 & & & & & & & \\
\hline \multicolumn{10}{|l|}{ Income in dollars } \\
\hline Up to $\$ 318.75$ & 157 & 91.3 & 0.713 & 0.399 & 1.039 & $0.965-1.117$ & - & - & - \\
\hline$\$ 318.75$ and over & 145 & 87.9 & & & & & & & \\
\hline \multicolumn{10}{|l|}{ Daily exposure } \\
\hline 6 hours and over & 120 & 77.9 & 22.957 & 0.001 & 0.819 & $0.749-0.895$ & 0.873 & 0.005 & $0.794-0.961$ \\
\hline Up to 6 hours & 197 & 95.2 & & & & & & & \\
\hline \multicolumn{10}{|l|}{ Weekly exposure } \\
\hline 5 days and over & 157 & 87.7 & 0.003 & 0.954 & 0.991 & $0.919-1.070$ & - & - & - \\
\hline Up to 5 days & 161 & 88.5 & & & & & & & \\
\hline \multicolumn{10}{|c|}{ Accumulated exposure } \\
\hline 8 years and over & 143 & 88.3 & 0.006 & 0.937 & 1.010 & $0.935-1.090$ & - & - & - \\
\hline Up to 8 years & 174 & 87.4 & & & & & & & \\
\hline \multicolumn{10}{|l|}{ Work start time } \\
\hline 09:00 h or later & 94 & 96.9 & 9.124 & 0.003 & 1.147 & $1.077-1.222$ & 1.055 & 0.121 & $0.986-1.129$ \\
\hline before 09:00h & 223 & 84.5 & & & & & & & \\
\hline \multicolumn{10}{|l|}{ Work finishing time } \\
\hline $16: 00 \mathrm{~h}$ or later & 107 & 79.3 & 13.488 & 0.001 & 0.853 & $0.777-0.937$ & 0.939 & 0.186 & $0.855-1.031$ \\
\hline Before 16:00h & 210 & 92.9 & & & & & & & \\
\hline \multicolumn{10}{|l|}{ Photoprotection } \\
\hline No & 53 & 73.6 & 15.431 & 0.001 & 0.806 & $0.698-0.929$ & 0.833 & 0.033 & $0.704-0.986$ \\
\hline Yes & 265 & 91.4 & & & & & & & \\
\hline \multicolumn{10}{|l|}{ Sunscreen use } \\
\hline No & 180 & 85.3 & 2.438 & 0.118 & 0.934 & 0.867-1.006 & 0.943 & 0.143 & $0.871-1.020$ \\
\hline Yes & 137 & 91.3 & & & & & & & \\
\hline Use of a Cap/Hat & & & & & & & & & \\
\hline No & 97 & 79.5 & 10.728 & 0,001 & 0,864 & $0.784-0.952$ & 1.015 & 0.785 & $0.913-1.128$ \\
\hline Yes & 220 & 92.1 & & & & & & & \\
\hline Skin type & & & & & & & & & \\
\hline Fair & 94 & 81.7 & 5.421 & 0.020 & 0.899 & $0.817-0.988$ & 0.920 & 0.058 & $0.844-1.003$ \\
\hline Dark/Black & 221 & 90.9 & & & & & & & \\
\hline Habit & & & & & & & & & \\
\hline Yes & 160 & 87.4 & 0.007 & 0.934 & 0.991 & $0.917-1.069$ & - & - & - \\
\hline No & 158 & 88.3 & & & & & & & \\
\hline Alcohol consumption & & & & & & & & & \\
\hline Yes & 126 & 86.9 & 0.083 & 0.774 & 0.982 & $0.907-1.063$ & - & - & - \\
\hline No & 192 & 88.5 & & & & & & & \\
\hline Smoking & & & & & & & & & \\
\hline Yes & 81 & 90.0 & 0.287 & 0.592 & 1.033 & $0.951-1.122$ & - & - & - \\
\hline No & 237 & 87.1 & & & & & & & \\
\hline
\end{tabular}




\section{Discussion}

Studies relating sociodemographic, occupational and health factors with type of work, considering sun exposure, are scarce in the literature. Research, analysis and interpretation of data is mostly simplified. This analytical approach is possible in cross-sectional studies since the design allows for the grouping of data from different bases, ranging from biological aspects of the individual to the occupations of participants involved. The accumulation changes in the genetic material of the cell depends on various factors such as endogenous sex, age and genetic makeup, and exogenous as consumption habits, feeding, drug use, exposure to chemicals, etc. The analysis of the combination of these endogenous factors for epidemiology and exogenous aims infer the individual risk of a worker likely to develop cancer compared to a given occupation". Furthermore, it promotes the dissemination of measures considered essential in reducing accidents and primary prevention of pathologies.

Subjects considered outdoor workers were those engaged in work around noon when peak ultraviolet radiation was recorded. Occupations related to this category typically extend over several years and exposure to ultraviolet rays generally occurs several times a week ${ }^{10}$. Individuals would be directly susceptible to damaged caused by sun exposure. On the other hand, those working in kiosks, hotels, bars and handicraft centers along the beaches studied were categorized as indoor.

The number of indoor workers observed in this study was lower in comparison to the outdoor category. A larger sample of subjects in the former would permit better data distribution. Conducting data collection during the low season, with less tourist traffic, allowed for the participation of individuals who regularly worked at the locations studied. It was expected that most of the sample would have a significant work history.

Of course, men are more likely to occupy jobs related to sun exposure, whether due to endurance or a greater need for physical strength ${ }^{11}$. ${ }^{14}$. Differences in risk behaviors related to the sun among occupations may reflect, in part, local cultural habits and type of photoprotection.

Composition of work groups differs considerably between the sexes. Women were more prevalent in studies of aquatic and recreational occupations, while men predominate in agriculture, services, construction, transport, postal services and the ski industry ${ }^{15}$.

The schooling level of the population investigated may corroborate these socioeconomic data. In addition to working more exposed to the environment, individuals who study less also earn proportionally less and work longer. Since it is important to collect data that illustrate a social parameter essential in understanding the damage profile of a certain disease within a population, the variable years of schooling was assessed. A link between lack of knowledge regarding the correct use of prevention methods, essential in carrying out occupational activities involving sun exposure, combined with the likely difficulty of access to healthcare services may explain the occurrence of a particular occupational disease.

When analyzing occupational variables related to time, outdoor workers were generally exposed to the sun for less daily hours during their work activities, 42 corresponding to peak solar radiation times between 09:00 and 16:00. Among factors that cause distortions and reduce the validity of epidemiological studies, exposure measurement stands out ${ }^{16}$. The occurrence of bias depends on the instrument used and its improper implementation, as well as the characteristics and sensitivity of the interviewed ${ }^{17}$.

Occupational variables referring to photoprotection measures revealed that most workers protected themselves from ultraviolet radiation. Indoor workers reported taking less photoprotection measures when compared to outdoor workers. This may be due to lack of knowledge regarding the indirect action of ultraviolet rays when reflected off beach sand, and the way photoprotection measures are being and have been implemented over time. Another possible explanation for that occupational exposure is that its use wasn't evidenced during the research. Recently, Salicio et al. ${ }^{18}$ analysed lung function in workers of ceramic industries in Várzea Grande - Mato Grosso. The workers have reported use of equipment Personal Protective Equipment (PPE) such as masks and gloves, but its use wasn't observed by most of the staff during our work field, although, from the point of view of ergonomic comfort, its use is becomes almost unfeasible under extreme temperatures next to ovens.

One effect observed by researchers among individuals exposed to the sun is the "sunscreen 
paradox": those using sunscreen with higher protection factors were the most prone to sunburn. McCarthy et al. ${ }^{19}$ established that, among beachgoers, those using sunscreen with larger protection factors exhibited greater frequency of sunburn compared to those applying low factor protection or those not using sunscreen. In a study on sunscreen use in children and its relationship with nevi, Autier et al..$^{20}$ concluded that a rise in the number of nevi was related to increased sun exposure and sunscreen use. At higher exposure levels, the nevi count in children who always applied sunscreen was twice as high as in those who never used it.

The ideal sunscreen for preventing burns, photoaging and even skin cancer, must meet four criteria in order to be effective: the technology involved in its production, evaluation of product performance, standards and use patterns and, above all, correct, even and repeated application ${ }^{21}$.

Photoprotectors are generally used incorrectly, especially in regard to protection factor, the amount of protection applied and intervals between applications. Inadequate protection occurs when the photoprotection factor is very low compared to duration or intensity of sun exposure; when an insufficient amount is used and when it is not applied prior to exposure. It is well known that sunscreen use diverges significantly from recommendations, a fact demonstrated by several studies ${ }^{22-25}$.

El Sayed et al. found a higher prevalence of sunburn among young photoprotection users. Most individuals diagnosed with lesions used protection at the time, demonstrating the inadequate use reported by the authors. "Subjects felt protected and extended their sun exposure, or did not reapply the product at recommended intervals"26,27.

The present study used some self-reported information, which may call into question or cast doubt on its results. The importance of this type of information should not be disregarded despite its known limitations. Time variables related to occupation and those involving photoprotection measures and habits are included in this context.

\section{Conclusion}

It was found that outdoor jobs were mostly occupied by men and workers with up to 6 years of schooling, who used photoprotection and were exposed to the sun for up to 6 hours a day.

Therefore, this study aimed to contribute towards a greater understanding by professionals in healthcare, the scientific community and health authorities regarding epidemiological aspects of jobs performed by beach workers, and particularly to warn against the harmful effects of UV radiation on health, primarily among those under intense and chronic exposure.

It is essential to intensify educational and preventive measures, as well as ensure appropriate remedial measures for this population and labor policies related to worker's health.

\section{Collaborations}

EES Lucena and KC Lima were responsible for the design of the study. EES Lucena, DCB Costa, EJD Silveira and KC Lima participated in data analysis and draft of the text.

\section{Acknowledgements}

We thank the fundings bodies: Coordination Improvement of Higher Education Personnel (CAPES) and UFRN Dermatology Departament. 
1. Ribeiro FSN, Wünsch Filho V. Retrospective evaluation of occupational exposure to carcinogens: an epidemiological approach and application to health surveillance. Cad Saude Publica 2004; 20(4):881-890.

2. Asmus CIRF, Ferreira HP. Epidemiologia e Saúde do Trabalhador. In: Medronho RA, Bloch KV, organizadores. Epidemiologia. São Paulo: Atheneu; 2006. p. 385-402.

3. Melia J, Bulman A. Sunburn and tanning in a British population. J Pub Health Med 1995; 17(2):223229.

4. Robinson JK, Rigel DS, Amonette RA. Trends in sun exposure knowledge, attitudes and behaviors: 1986 to 1996. J Am Acad Dermatol 1997; 37(2 Pt 1):179-186.

5. Rouquayrol MZ, Almeida Filho N. Epidemiology and Health. Rio de Janeiro: MEDSI; 2003.

6. Brasil. Ministério da Saúde (MS). Conselho Nacional de Saúde. Resolução nº 196 de 10 de outubro de 1996. Diretrizes e Normas Regulamentadoras de Pesquisas Envolvendo Seres Humanos. Diário Oficial da União 1996; 16 out.

7. Lucena EES. Prevalence and associated factors for lip and perioral lesions from Sun Exposure in beach workers. Tesis. BLO-Brazilian Library of Odontology 2011, ID: 35878.

8. Fitzpatrick TB. The validity and practicality of sunreactive skin types I through VI. Arch Dermatol 1988; 124(6):869-871.

9. Gattás GJF, Segre M, Filho VW. Genética, biologia molecular e ética: as relações trabalho e saúde. Cien Saude Colet 2002; 7(1):159-167.

10. Glanz K, Buller DB, Soraya M. Reducing ultraviolet radiation exposure among outdoor workers: State of the evidence and recommendations. Environ Health 2007; 6(22):1-11.

11. Memon AA, Tomenson JÁ, Bothwell J, Friedmann PS. Prevalence of solar damage and actinic keratosis in a Merseyside population. Br J Dermatol 2000; 142(6):1154-1159.

12. Frost CA, Green AC, Williams GM. The prevalence and determinants of solar keratoses at a subtropical latitude. Br J Dermatol 1998; 139(6):1033-1039.

13. Kennedy C, Bajdik CD, Willemze R, De Gruijl FR, Bouwes Bavinck JN; Leiden Skin Cancer Study. The influence of painful sunburns and lifetime sun exposure in the risk of actinic keratoses, seborrheic warts, melanocytic nevi, atypical nevi, and skin cancer. I Invest Dermatol 2003; 120(6):1087-1093.

14. Araki K, Nagano T, Ueda M, Washio F, Watanabe S, Yamaguchi N, Ichihashi $M$. Incidence of skin cancers and precancerous lesions in Japanese- risk factors and prevention. J Epidemiol 1999; 9(Supl. 6):S14S21.
15. Steffen AD, Glanz K, Wilkens LR. Dentifying latent classes of adults at risk Risk for Skin Cancer Based on Constitutional Risk and Sun Protection Behavior. Cancer Epidemiol Biomarkers Prev 2007; 16(7): 1422-1427.

16. Goldberg M, Hémon D. Occupational epidemiology and assessment of exposure. Int J Epidemiol 1993; 22(Supl. 2):S5-S8.

17. Armstrong BK, White E, Saracci R. Principles of exposure measurements in epidemiology. New York: Oxford University Press; 1992.

18. Salicio VSMM, Botelho C, Silva AMC, Salicio MA. Fatores associados às alterações da função pulmonar em trabalhadores de indústria de cerâmica. Cien Saude Colet 2013; 18(5):1353-1360.

19. McCarthy EM, Ethridqe KP, Wagner RF. Beach Holiday sunburn: the sunscreen paradox and gender differences. Cutis 1999; 64(1):37-42.

20. Autier P, Doré JF, Cattaruzza MS, Renard F, Luther H, Gentiloni-Silverj F, Zantedeschi E, Mezzetti M, Monjaud I, Andry M, Osborn JF, Grivegnée AR. Sunscreen use, wearing clothes, and number of nevi in 6 to 7-year-old European children. J Natl Cancer Inst 1998; 90(24):1873-1880.

21. Osterwalder U, Herzog B. The long way towards the ideal sunscreen - where we stand and what still needs to be done. Photochem Photobiol Sci 2010; 9(4):470-481.

22. Diffey BL. People do not apply enough sunscreen for protection. Br Med J 1996; 313(7062):942.

23. Azurdia RM, Pagliaro JA, Diffey BL, Rhodes LE. Sunscreen application by photosensitive patients is inadequate for protection. Br J Dermatol 1999; 140(2):255-258.

24. Bech-Thompson N, Wulf HC. Sunbathers application of sunscreen is probably inadequate to obtain the Sun protection factor assigned to the preparation. Photodermatol Photoimmunol Photomed 1992; 9(6):242-244.

25. Stokes R, Diffey B. How well are sunscreen users protected? Photodermatol Photoimmunol Photomed 1997; 13(5-6):186-188.

26. El Sayed F, Ammoury A, Nakhle F, Dhaybi R, Marguery MC. Photoprotection in teenagers. Photodermatol Photoimmunol Photomed 2006; 22(1):18-21.

27. Davis KJ, Cokkinides VE, Weinstock MA, O'Connell MC, Wingo PA. Summer sunburn and sun exposure among US youths ages 11 to 18: national prevalence and associated factors. Pediatrics 2002; 110(1 Pt 1):27-35.

Artigo apresentado em 16/03/2013

Aprovado em 18/08/2013

Versão final apresentada em 29/08/2013 
